Original Paper

\title{
Influence on Electricity Grid Composition and Petroleum Refinery Process by Installation of Residual Oil IGCC
}

\author{
Haruaki ONO*1, Keishi ARAKI*2, Takuya ODA*3, \\ Takahiko MIYAZAKI**4, Yuki UEDA*4, and Atsushi AKISAWA*4 \\ (Received April 2, 2010)
}

\author{
石油残渣 IGCC の適用が電源構成と石油精製工程に与える影響 \\ 小野春明*1，荒木圭司 ${ }^{* 2}$ ，小田拓也*3，宮崎隆彦*4，上田祐樹*4，秋澤 淳*4
}

\begin{abstract}
Life of energy infrastructures such as power generation plants and petroleum refineries is more than 40 years, and it takes long time for changing over technology generations. For studying the future energy infrastructure, it is required to consider several aspects: change of supply conditions of primary energies, change of energy conversion technologies and change of demand side of secondary energies. According to the energy outlook of Japan, dependency on petroleum will be reduced while requirement for electricity will be increased. Availability of light crude oil will become tight while demand for lighter products will increase relatively with less demand for heavier products. This means it is crucial to adopt some technologies for processing heavy bottoms. We constructed an integrated model including grid power generation system and petroleum refining system to study the change of energy conversion sectors. It is a multi-period linear programming model covering 2000 to 2050. Gasification technologies, such as Resid IGCC and Gasification Hydrogen Unit, are introduced as bottom processing technologies in addition to conventional thermal and hydro cracking. We found following results: (1) Using only heaviest crude oil, lighter products can be supplied by cracking facilities, while residues are fed to power generation then exported to power grid. (2) Potential of electricity generated by Resid IGCC is about $5 \%$ of total Japanese power demand, with generation capacity $7 \mathrm{GW}$. (3) Hydrogen unit is also converted from conventional steam reformer using light feed stocks to gasification hydrogen unit using thermal cracked residues.
\end{abstract}

\section{Key Words}

Residual oil, IGCC, Petroleum refinery system, Grid power system, Oil refinery process, Cost minimum

\section{1. はじめに}

石油は21世紀半ばでも世界における一次エネルギー供給量 の約 3 割を占めると考えられており，主要なエネルギーと言 える11。一方，世界的なエネルギー需要の高まりは資源制約問 題を更に加速させる可能性があり，石油を安定的・合理的に 利用する必要がある。

* 1 BDF JAPAN Corporation 3-2, Ichibancho, Chiyoda-ku, Tokyo 102-0082, Japan

* 2 Tokyo University of Agriculture and Technology 2-24-16, Nakacho, Koganei-shi, Tokyo 184-0012, Japan

* 3 Tokyo Institute of Technology 2-12-1-I6-25, Ookayama, Meguro-ku, Tokyo 152-0033, Japan

* 4 Tokyo University of Agriculture and Technology 2-24-16, Nakacho, Koganei-shi, Tokyo 184-0012, Japan
日本の石油需要は, 将来的には減少することが予想されて いるものの，2030年の日本の一次エネルギー消費の 4 割弱を 占めると考えられており，依然としてエネルギーの主役であ る2)。但し, 石油製品の需要の内訳を見れば, C重油の減少と 軽質化 (白油化) が進むと考えられる ${ }^{3)} 。$ 石油は，原油を精製 して複数の製品を製造する連産品であり，白油と呼ばれる軽

\footnotetext{
* 1 BDF JAPAN (株) 干 102-0082 東京都千代田区一番町 3-2

* 2 東京農工大学大学院生物システム応用科学研究科 干 184-0012 東京都小金井市中町 2-24-16

* 3 東京工業大学ソリューション研究機構 干 152-0033 東京都目黑区大岡山 2-12-1-I6-25

*4 東京農工大学大学院工学研究院 干 184-0012 東京都小金井市中町 2-24-16
} 
質の製品だけを製造することはできないので，原油に含まれ る重質分を有効に利用する方法を適切に組み込むことが重要 である。更に，石油需要の世界的な高まりによって使い易い 軽質原油が稀少になり, 比較的埋蔵量の豊富な重質原油なら びに超重質石油資源を利用することになる可能性がある。こ の際，原油に含まれる重質分は増加するため，重質分を有効 利用する必要性が, 更に高まると言える。

石油残渣IGCC (Residual Oil Integrated Gasification Combined Cycle，以下RIGC)は，原油の精製後に残る重質な石油残渣を ガス化することによって高効率に発電をすることができる。C 重油の需要が大幅に減少するので, 重質分を分解して軽質分 を有効利用し，その残渣で発電することができれば，石油の 需給双方を考慮した合理的なエネルギー変換システムを構築 することに寄与できるであろう。

本論文では，日本の石油精製設備を総括して石油精製シス テムと呼ぶ。石油精製システムは，1960～1970年代に基盤整 備されたものが多いが，設備の多くは耐用年数が 40 年以上あ るため, 最近になって更新の時期を迎えつつある。耐用年数 の長さと, 石油製品が連産品であることから，40～50年先の 状況を考慮した技術選択を示す必要がある。更に，石油精製 システムだけでなく, RIGCは発電システムでもあるので電源 としての位置づをを考慮する必要もある。将来的には, 石油 精製システムは原油の変換拠点としてだけでなく, 非在来型 石油資源や，非石油資源，リサイクル資源などとも融合した， エネルギー転換拠点になる可能性がある。RIGCは，これらの 鍵となるガス化工程を含み，商用段階に最も近い技術の一つ と言える。

本研究では, 石油精製システムと電源システムの双方を考 慮したエネルギーシステムの解析を通じて, 石油残渣の利用 に関する総合的な方策を示すことを目指している。本報告で は, 石油精製システムと電源システムの双方を統合した最適 化モデルを構築し，2050年までの長期的視点に立って石油残 渣IGCCの位置づけを明らかにすることを目的とする。石油精 製システムの詳細を動学的に考慮した研究事例は, 他に例が ない。本モデルは, 今後, 運輸部門のシステム代替を考慮し たものに発展させる予定である。

\section{2. 統合モデル}

原油の重質化と, 石油製品需要の白油化, RIGCの導入に伴 う電源構成の変化等を考慮して, 電源システムと石油精製シ ステムの両方の技術選択を評価するための最適化モデルを構 築する。従来, 電源モデルと石油精製モデルは別々に最適化 されてきた。本研究で構築するモデルは，両者間の燃料と電 力の融通を考虑して統合した。これを統合モデルと呼ぶ。統 合モデルは，電源モデルと石油精製モデルに大別され，その 詳細は次章で説明される。ここでは統合モデルの基本的構造 を説明する。

Fig. 1亿統合モデルフローを示す。電源モデルでは，石炭· 石油・ LNG - 原子力・水力等の各発電所で発電を行い, 所与 の電力需要を満たす。この際の各機器の発電設備容量や発電

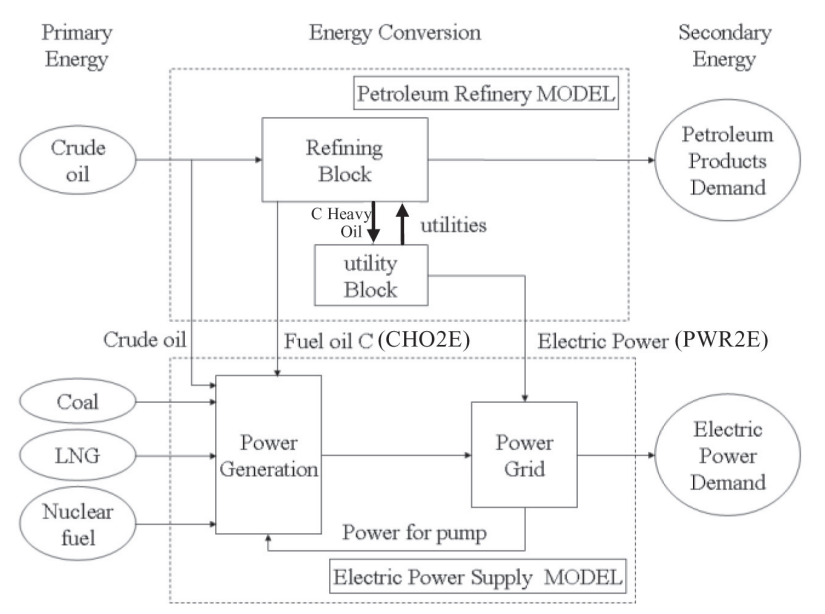

Fig. 1 Integrated model

出力が最適化される。電源モデルは, 後述する石油精製モデ ルから，電力用の重油や余剩電力を受ける。

石油精製モデルでは，特徵的な 7 種類の原油を原料として， 多様な所与の石油製品を生産する。石油精製工程は細分化し てモデル化されると共に, 石油精製工程で消費する電力, 燃 料, 蒸気等のユーティリティも併せてモデル化される。この 際, 電力や発電用 C 重油 $(\mathrm{CHO} 2 \mathrm{E})$ に余剩があれば, 電源モデ ルによって調整される。この授受によって両者が統合される。

統合モデルは，技術選択を考慮するため 2000 年から 2050 年までの 50 年間を評価する。 1 期 5 年の計 11 期とした。評価 期間内の技術選択は，2000年までに設置された設備構成の影 響を受ける。電源・石油精製の両モデルに対して, 統計資料 を元に過去 40 年間の時期別装置ストックをモデルに与えた。

目的関数は総費用の最小化とした。 50 年間の固定費 (設備 費）と可変費（燃料費，触媒費）の合計を線形計画法により 最小化する。な掞各期の費用は割引率を $3 \%$ として2000年基 準で現在価值換算した。電源モデルと石油精製モデルの間の 取引価格は考慮されておらず，電力会社と石油精製会社が協 力して日本全体のエネルギーコストを最小化するような技術 選択を示すことになる。原油や石炭には現実社会では課税さ れるが，本モデルでは技術ポテンシャルを評価するために実 施するものであり，諸税は考慮していない。

\section{3. 電源モデルと石油精製モデル}

本章では, 統合モデルを構成する電源モデルと石油精製モ デルについて，それぞれ説明する。

\section{1 電源モデル}

\section{1 .1 概 要}

電源モデルは Fig. 2 のように各種の電源設備を介して燃料 から電力に変換するモデルである。石油火力発電の燃料とな る原油，C重油が，2.で説明した統合モデル内の石油精製モデ ルから内生的に与えられる。発電に使われる燃料は生焚原油 (Crude Oil), 電力用 C 重油 (CHO2E), 石炭 (Coal), LNG (Liquefied Natural Gas)，核燃料（Nuclear Fuel）の 6 種類を 想定した。電源はOILF, COF, CIGC, LNF, LNC, NP, HYDR, 


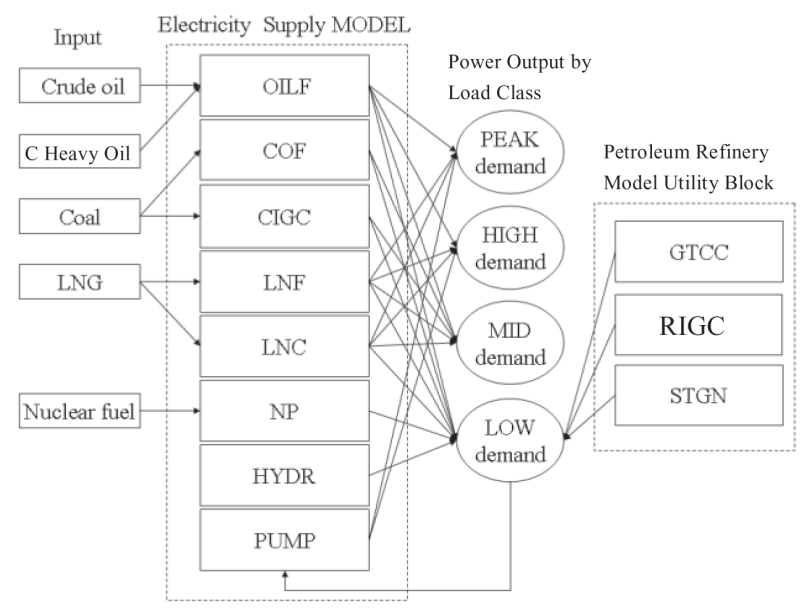

Fig. 2 Electronic power supply model

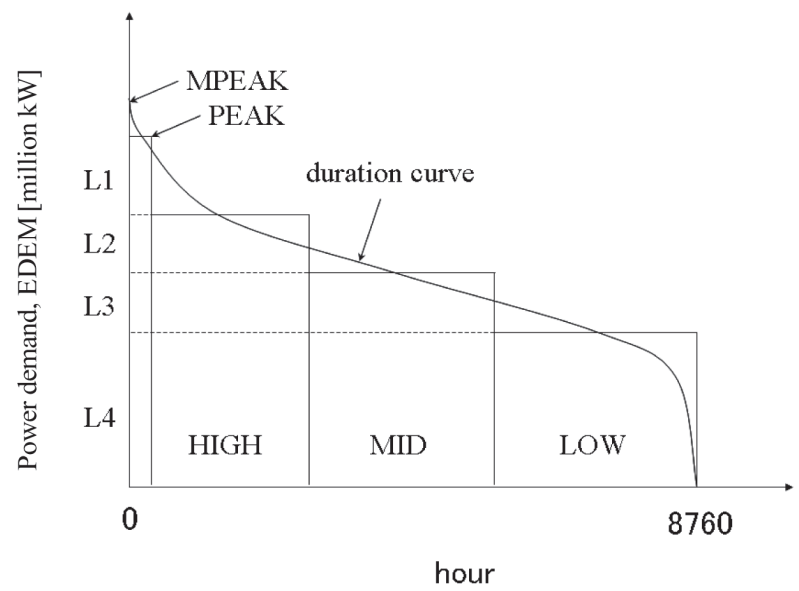

Fig. 3 Approximate load duration curve

PUMPの 8 種類を想定し, 発電燃料と電源はFig. 2のように対 応している。電力需要は，経済産業省の資料4) を参考に，2000 年から 2030 年に掛けて電力需要が 1.3 倍に増加することを, 2000 年から 2050 年は同 1.5 倍に増加することを想定した。こ れを元に，Fig. 3に示すような近似負荷持続曲線を与えた。近 似負荷持続曲線とは負荷持続曲線を段階的に 4 つに近似した
ものである6)。それらの負荷のうち，大きい順にPEAK，HIGH， MID, LOW需要とする。これら 4 区分の電力需要に対して, 式 (1)に示すような電力の需給バランスを満たす。式(1)の右辺 は，近似負荷曲線の 4 区分の差で与えられる時間带別電力需 要EDEMである。式(1)の左辺は, EDEMに対応した電源の運 用別負荷 LVAL を示している。LVAL はそれぞれ，ピーク負 荷用運転 (L1), ミドル負荷用運転 (L2, L3), ベース負荷用 運転 (L4)である。ベース負荷には揚水負荷 PU が含まれる。各 電源にはTable 1に示すようなパラメータが与えられ7), Fig. 3 に示した電力需要を満たす。

$$
\begin{aligned}
& \mathrm{LVAL}_{1}=\mathrm{EDEM}_{\mathrm{PEAK}}-\mathrm{EDEMHIGH}_{\mathrm{H}} \\
& \mathrm{LVAL}_{\mathrm{L} 2}=\mathrm{EDEM}_{\mathrm{HIGH}}-\mathrm{EDEM}_{\mathrm{MID}} \\
& \mathrm{LVALL}_{3}=\mathrm{EDEM}_{\mathrm{MID}}-\mathrm{EDEM}_{\mathrm{LOW}}-\mathrm{PU} \\
& \mathrm{LVAL}_{\mathrm{L}}=\mathrm{EDEM}_{\mathrm{LOW}}+\mathrm{PU}
\end{aligned}
$$

電源の耐用年数は40年以上ある。各期において稼働可能な 既存電源は, 過去に設置された電源のうち, 耐用年数内であ る電源の集合となる。現実には修繕や転換をすることによっ て耐用年数は変動するが，本モデルでは，耐用年数はTable 1 に示された值で固定し, 修繥や転換等は再現しない。期別の 既存電源を各電源の過去の設置履歴 ${ }^{11)}$ から算出して与えた。 既存電源が廃止されることに伴い，2005年以降は電源の新設 が発生する。電源の選択を含め, 最適化モデルにより算出さ れる。

\subsection{2 定式化}

\section{(1) 需要充足}

全電源の LVAL 別出力の総和が, 近似負荷持続曲線で表さ れる電力需要と揚水動力需要を賄う。電源モデルの LVAL 別 出力をX，各電源設備の集合をI，電源所内率をLS，石油精製 モデルの余剩電力を XfrP とすると，式(2)のように計算され る。

$$
\sum\left[X_{I} \times\left(1-L S_{I}\right)\right]+X f r P \geqq L V A L
$$

\begin{tabular}{|c|c|c|c|c|c|c|}
\hline & $\begin{array}{l}\text { Generator } \\
\text { Type }\end{array}$ & $\begin{array}{c}\text { Load } \\
\text { classification }\end{array}$ & $\begin{array}{l}\text { Generating } \\
\text { efficiency } \\
{[\%(\mathrm{HHV})]}\end{array}$ & $\begin{array}{c}\text { Unit construction } \\
\text { cost } \\
{[¥ / \mathrm{W}]}\end{array}$ & $\begin{array}{c}\text { Internal } \\
\text { consumption rate } \\
\left.[\%]^{8)} \sim 10\right)\end{array}$ & $\begin{array}{c}\text { Equipment } \\
\text { life } \\
\text { [year] }\end{array}$ \\
\hline \multirow{8}{*}{$\begin{array}{l}\text { Electric power } \\
\text { supply model }\end{array}$} & OILF & L1,L2,L3,L4 & 38.1 & 190 & 5.4 & 40 \\
\hline & $\mathrm{COF}$ & L3,L4 & 41.8 & 300 & 5.0 & 40 \\
\hline & CIGC & L3,L4 & 47 & 330 & 5.0 & 40 \\
\hline & LNF & L1,L2,L3,L4 & 38.6 & 200 & 5.4 & 40 \\
\hline & LNC & L1,L2,L3,L4 & 55 & 232 & 2.5 & 40 \\
\hline & NP & L4 & 38 & 310 & 4.4 & 50 \\
\hline & HYDR & L4 & 100 & 600 & 0.5 & 60 \\
\hline & PUMP & L1,L2 & 100 & 196 & 0.5 & 60 \\
\hline \multirow{4}{*}{$\begin{array}{l}\text { Petroleum refinery } \\
\text { model }\end{array}$} & STGN & L4 & 40 & 100.0 & 4.5 & 40 \\
\hline & RIGC1 & L4 & 46 & 135.5 & 20.6 & 40 \\
\hline & RIGC2 & L4 & 51 & 141.2 & 10.5 & 40 \\
\hline & GTCC & L4 & 50 & 200.0 & 2.0 & 40 \\
\hline
\end{tabular}

(2)容量制約（MAX ピーク需要制約）

各電源の設備容量 $\mathrm{C}$ と石油精製モデルの発電設備容量

Table 1 Power generator property 
PWGNの総和は, 最大ピーク需要EDEMMPEAKに供給予備率SPA を付加した值よりも大きくなくてはならなく，式(3)のように 表される。供給予備率とは, 最大電力（一定期間内における ピーク需要時の電力負荷) に対して, 現有の発電設備が余分 に保有する容量の割合である。ここではSPAに $11.3 \%$ 与え た。

$$
\sum_{I}\left(C_{I}+P W G N_{I}\right) \geqq(1+S P A) \times E D E M_{M P E A K}
$$

(3) 設備の利用可能率

式(4)に示すように発電出力の上限は設備容量に利用可能率 AVAILを掛けたものとする。利用可能率とは各電源の定期点 検で利用できない設備を差し引くパラメータである。

$$
\sum_{I} X_{I, L} \leqq C_{I} \times A V A I L_{I}
$$

(4)揚水発電の制約式

揚水式発電とは夜間（L4）の電力を使って水を高い位置に 貯水し位置エネルギーに変換し，昼間（L1，L2）に放水する ことで発電を行い，負荷平準化に寄与する。揚水負荷を PU, LVAL別出力をXとすると，式(5)のように計算される。その 際, 式(6)に示すようにL4負荷帯で発生する揚水ポンプ動力 需要とL4負荷帯電力需要の和がミドル時間帯の電力需要より も大きくなってはならない。PUEFFは揚水発電のエネルギー 回収率を意味し，70\%とした。

$\mathrm{PU} \times \mathrm{PUEFF} \times \mathrm{TDEM}_{\mathrm{LOW}}=\mathrm{X}_{\mathrm{L} 1} \times \mathrm{TIMEL}_{\mathrm{L} 1}+\mathrm{X}_{\mathrm{L} 2} \times \mathrm{TIMEL}_{\mathrm{L} 2}$

$\mathrm{PU} \leqq \mathrm{EDEM}_{\mathrm{MID}}-\mathrm{EDEM}_{\text {Low }}$

(5) コスト

電源モデルの総コストECOST は固定費 FIX と変動費 FUEL の和であり, 式(7)のように表される。固定費とは設備償却費 と運転経費のことを言い, 変動費とは燃料調達費を言う。燃 料調達費のうち, 生焚火力用原油と電力用 C 重油は石油精製 モデルでカウントされる。各設備の減価償却期間を 15 年 ( 3 期償却）とし，期別の償却費を計算した。

$$
E C O S T=F I X+F U E L
$$

\section{2 石油精製モデル}

石油精製では，2.のFig. 1に示すように，原油から様々な石 油製品を生産する。これらの生産プロセスは石油精製モデル として記述され，2.に説明した統合モデルに組み入れられる。 石油精製モデルは, 精製工程と, ユーティリティの 2 つに大 別される。

\subsection{1 石油精製工程のモデル化}

石油精製モデルでは，原油から製品生産までの石油精製プ ロセスが細分化され, 複数の精製装置の集合体として記述さ れる。本研究では精製プロセスを, 蒸留, 脱硫, 改質, 分解 等の各装置群に区分し, 全工程をモデル化した。各工程では 単一あるいは複数の入力物質から, 装置の変換効率や用役消 費量を考慮して, 何らかの出力物質を得る。モデルでは, 最 終製品の生産量（需要量）を与えた上で, 投入する原油の種 類と量, 各装置の設備容量や生産量を最適化した。

一般に石油精製モデルは, 製品出荷単位である容積を基準
としてモデル化されることが多いが，本研究ではマスバラン スだけでなくエネルギーバランスも含めてモデル化するため に，質量ベースでモデル化した点に特徵がある。物質 $\mathrm{M}$ に対 して入力 $\mathrm{i}$ と出力 $\mathrm{j}$ があり, 変換効率 (あるいは得率) $\alpha$ で定 義されるとき，マスバランスは式(8)で示される。このとき， $\mathrm{k}$ 種のユーティリティ Jを消費する。ユーティリティ消費率と して $\beta$ を与えた。エネルギーバランスは式(9)で示される。

$$
\begin{aligned}
& \sum_{j} M_{j}=\sum_{i}\left(\alpha_{i j} \times M_{i}\right) \\
& \sum_{k} J_{k}=\sum_{i}\left(\beta_{i k} \times M_{i}\right)
\end{aligned}
$$

ある単一の原油を元にして, 主要な変換工程を示せば, Fig. 4 となる。左端の原油は, 常圧蒸留装置 (TOPP) を経て, 得ら れた抽出油を各二次装置に投入し, 分解 - 改質を施し, 右端 の最終製品が生産される。

各工程の変換効率は原油に応じて異なる。ここでは超重質 原油から超軽質原油と低硫黄原油，コンデンセート等，各夕 イプを代表する計 7 種の原油を与えた。油種の性状をTable 2 に示す ${ }^{12)}$ 。一般的に API 比重が小さい原油ほど重質であり， 精製できる白油は少なく, 石油残渣を多く含む。同時に, 重 質油は硫黄分が多く精製コストも高い。

Fig. 4 の右端の最終製品として 15 種を想定した。PLPG, PNAPH, PBENZ, PRG, REG, PKERO, PJO, PGO, AHO, CHO2E, CHO2F, PASFA, PSULF, PCOK, PLUBE がある。

原油は, 蒸留工程によって LHC, LPG, LN, HN, KERO, $\mathrm{GO}, \mathrm{AR}, \mathrm{VGO}, \mathrm{VR} の 9$ 種類に分離される。この後, 脱硫や 改質などを施すことによって, 最終製品 15 種を生産するに至 るまでに，約 50 種の中間物質を得る。

\subsection{2 物質物性值の設定}

(1) 各物質の品質・性状データ：中間物質等の計 48 種につい て, 密度 $[\mathrm{kg} / \mathrm{L}]$, 硫黄分 $[\mathrm{wt} \%]$, オクタン価, 動粘度 $[\mathrm{cSt}$, セタン価, 蒸気圧 $[\mathrm{kPa}]$ を, 全油種一定のパラメータとし て与えた ${ }^{13)}$ 〜16)。

(2) 石油製品の密度: 精製した後に得られる生産品 12 種につ いて，それぞれ密度を与えた ${ }^{13) － 16) 。 ~}$

(3) 蒸溜装置の密度および硫黄分:LHCやVR等の 9 物質を精 製する常圧蒸留・減圧蒸留では, 留出油であるために原油 種によって性状が異なるので原油種毎に, 得られる物質の 密度と硫黄分を与えた ${ }^{17)}$ 。

\subsection{3 各工程の得率}

各石油精製装置の出入力関係を規定する質量得率データは, 質量の単位を $[\mathrm{Mt}]$, 燃料 - 蒸気・電力の単位を $[\mathrm{PJ}]$ として与 えた。

常圧蒸留装置 (TOPP ; Atomospheric Distillation) と減圧蒸 留装置(VACU;Vacuum Distillation)の入力は各種原油であり, 入力油種によって得られる物質の比率が異なる。LHC等の 10 物質の得率デー夕を，原油毎に質量比率で与えると共に，そ れぞれの変換工程のユーティリティの入出力も与えた ${ }^{15)}$ 。

脱硫装置群および改質装置群, 高品質ガソリン基材製造装 


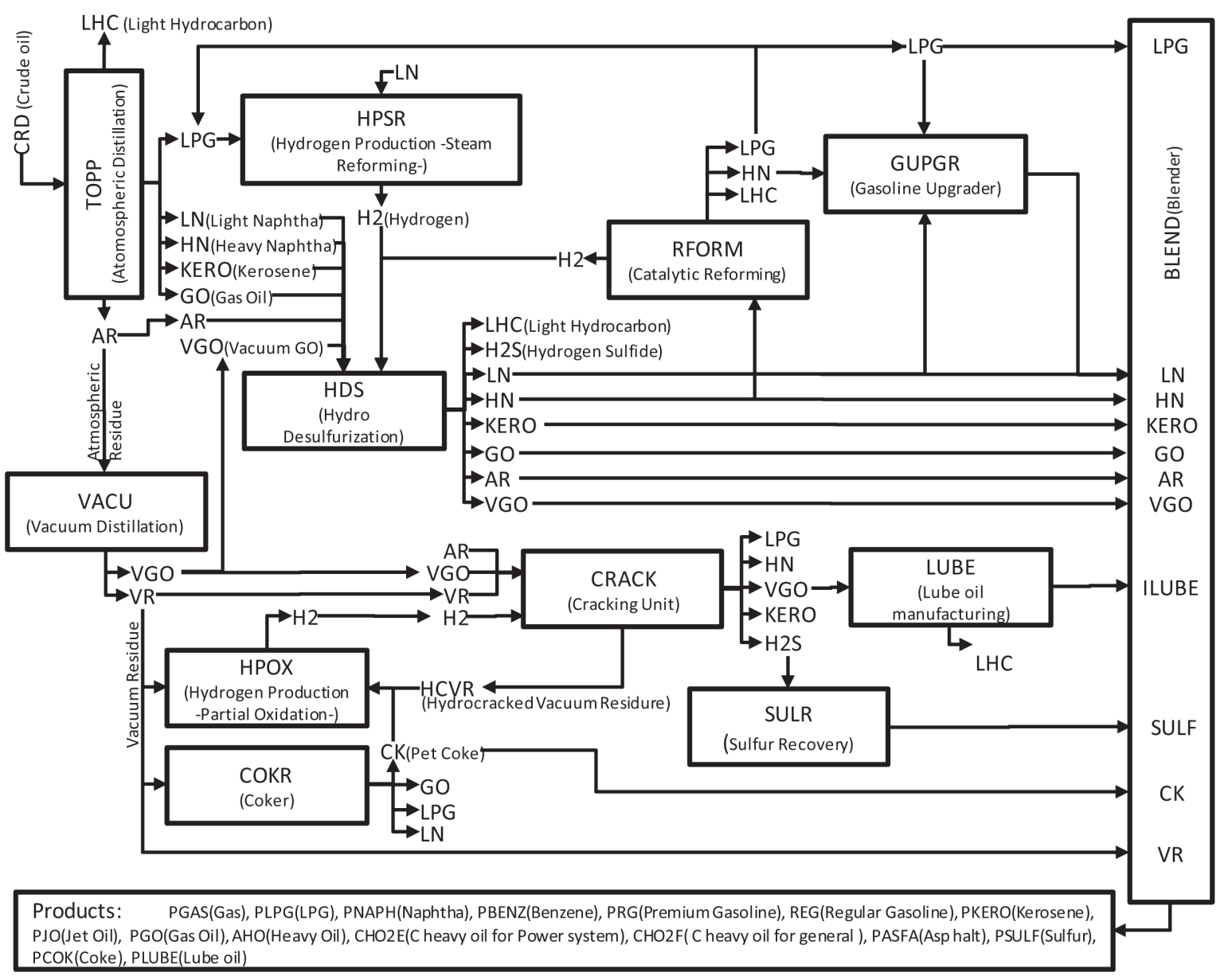

Fig.4(a) Refining Block

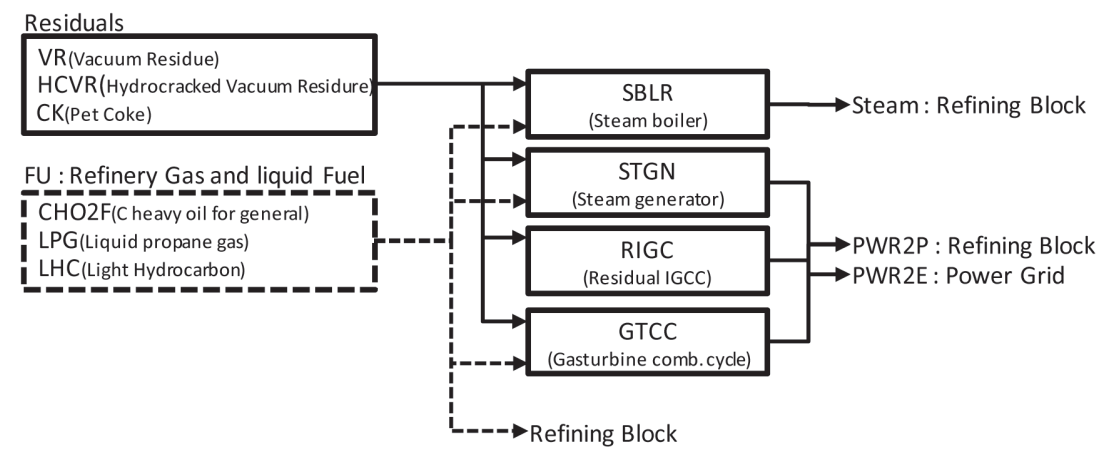

Fig.4(b) Utility Block

Fig. 4 Petroleum refinery model

Table 2 Crude oil properties

\begin{tabular}{c|c|c}
\hline Crude oil & API & $\begin{array}{c}\text { Density } \\
{[\mathrm{kg} / \mathrm{L}]}\end{array}$ \\
\hline RTW & 24 & 0.91 \\
\hline AHY & 27 & 0.89 \\
\hline ALT & 33 & 0.86 \\
\hline MUB & 40 & 0.83 \\
\hline AXL & 45 & 0.8 \\
\hline SLT & 34 & 0.85 \\
\hline TMC & 58 & 0.74 \\
\hline
\end{tabular}

置群, 分解装置群, 滑油製造·硫黄回収装置, 水素製造装置 群, 燃料調合装置の各々の工程の得率データを, 質量比率で 与えた ${ }^{13)}$ 。

\subsection{4 石油精製装置のコスト}

石油精製装置のコストは, 建設単価(固定費), 運転経費率 (固定費), 触媒・薬剤費 (変動費) に大別できる。それぞれ について設定した值をTable 3に示す。CF (Complexity Factor) とは，装置の製油所の中にある様々なタイプの装置の諸コス 卜を相互比較するために, 常圧蒸留装置を基準 $=1.0$ として設 
Table 3 Property of Refining Process

\begin{tabular}{c|c|c|c}
\hline $\begin{array}{c}\text { Refining } \\
\text { Process }\end{array}$ & CF & $\begin{array}{c}\text { Construction cost } \\
{[G ¥ / G L][G ¥ / \mathrm{Mt}]}\end{array}$ & $\begin{array}{c}\text { Variable cost } \\
{[\mathrm{G} ¥ / \mathrm{GL}]}\end{array}$ \\
\hline TOPP & 1.0 & 1.44 & 0.000 \\
\hline VACU & 1.0 & 1.44 & 0.000 \\
\hline NHDS & 2.0 & 2.88 & 0.002 \\
\hline KHDS & 2.5 & 3.60 & 0.010 \\
\hline GHDS & 2.5 & 3.60 & 0.020 \\
\hline VHDS & 3.5 & 5.04 & 0.043 \\
\hline ARHDS & 7.4 & 10.66 & 0.271 \\
\hline CGSD & 2.5 & 3.60 & 0.005 \\
\hline SRRF & 3.4 & 4.90 & 0.000 \\
\hline CCRF & 3.6 & 5.19 & 0.000 \\
\hline DBENZ & 1.1 & 1.58 & 0.000 \\
\hline ALKY & 8.0 & 11.52 & 0.450 \\
\hline ISOM & 4.0 & 5.76 & 0.005 \\
\hline MTBE & 4.0 & 5.76 & 0.000 \\
\hline VHCR & 7.0 & 10.08 & 0.150 \\
\hline H-OIL & 11.0 & 15.85 & 1.100 \\
\hline VFCC & 8.2 & 11.81 & 0.110 \\
\hline RFCC & 10.0 & 14.41 & 1.100 \\
\hline COKR & 7.5 & 10.80 & 0.000 \\
\hline LUBE & & - & 0.000 \\
\hline SULR & & 75.75 & 0.000 \\
\hline HPSR & & 24.26 & 0.000 \\
\hline HPOX & & 32.37 & 0.000 \\
\hline SBLR & & 6.86 & 0.000 \\
\hline
\end{tabular}

備の技術的複雑性を指標化したものであり, コストとほぼ比 例することが経験的に判っている值である。本モデルではこ れを建設単価の推定に用いた。变動費は通油量に比例するも のとした。運転経費率は，装置に関わらず4[GYen/GL]また は 4[GYen/Mt]の一定値を与えた。

\subsection{5 石油精製装置ストック量の推定}

本モデルでは, 例えば灯油脱硫装置と軽油脱硫装置と分離 して考慮しているが，既存資料 ${ }^{18)}$ では同一に扱われるなど， 充分な情報が得られない。その他の装置についても情報が不 完全である。そこで，2004年度時点における石油精製能力か ら各精製能力を割り出し, 既存資料に割り戻して精製能力履歴 を推定した。但し, 情報の不足から, 脱ベンゼン装置と分解ガ ソリン選択脱硫装置については既設設備ゼロとした。以上を踏 まえて推定した装置別精製装置設置履歴データをTable 4に示 す。

\subsection{6 製品需要と輸入ナフサ}

石油製品の需要は, 2000 年度の国内販売量を基準とし, 2030年迄に, 輸送用燃料需要30\%削減させ，かつ $20 \%$ を非石

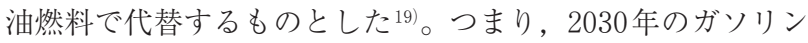
や軽油等輸送用燃料の需要が $56 \%$ となるよう各期一定の割合 で減少することを想定した。2030年以降も, 同じ割合で減少 し続ける需要を与えた。なお, ジェット燃料油需要は現状維 持とした。他, 灯油, A 重油, C 重油等燃料の需要は 2030 年 の時点で $30 \%$ 減少とした ${ }^{13)}$ 。各製品の生産量を全て所与の值 にするとモデルが解を与えない可能性がある。製油所ガス,

Table 4 Refining Process Stock by Construction Period (GL/year)

\begin{tabular}{c|c|c|c|c|c|c|c|c|c}
\hline \multirow{2}{*}{ Refining Process Type } & $1995^{-}$ & $1990^{-}$ & $1985^{-}$ & $1980^{-}$ & $1975^{-}$ & $1970^{-}$ & $\begin{array}{c}1965^{-} \\
1960^{-}\end{array}$ & $\begin{array}{c}1955^{-} \\
1965\end{array}$ \\
\hline TOPP & 0 & 0 & 41.67 & 0 & 0 & & 131.80 & 95.82 & 80.44 \\
\hline VACU & 0 & 1.10 & 0.00 & 0 & 0 & 2.90 & 54.15 & 36.50 & 6.73 \\
\hline NHDS & 0 & 3.71 & 56.06 & 0 & 0 & 0 & 0 & 0 & 0 \\
\hline KHDS & 0 & 12.12 & 70.43 & 0 & 0 & 0 & 0 & 0 & 0 \\
\hline GHDS & 0 & 7.90 & 45.87 & 0 & 0 & 0 & 0 & 0 & 0 \\
\hline VHDS & 0 & 5.41 & 3.20 & 0 & 0 & 5.91 & 32.23 & 13.13 & 0 \\
\hline ARHDS & 0 & 3.41 & 2.02 & 0 & 0 & 3.73 & 20.34 & 8.29 & 0 \\
\hline CGSD & 0 & 0 & 0 & 0 & 0 & 0.00 & 0.00 & 0.00 & 0 \\
\hline SRRF & 0 & 0.84 & 3.14 & 3.45 & 0 & 0.00 & 6.90 & 4.49 & 4.68 \\
\hline CCRF & 0 & 0.90 & 3.36 & 3.69 & 0 & 0.00 & 7.38 & 4.80 & 5.01 \\
\hline DBENZ & 0 & 0 & 0 & 0 & 0 & 0 & 0 & 0 & 0 \\
\hline ALKY & 0 & 1.22 & 1.45 & 2.84 & 0 & 0 & 0 & 0 & 0 \\
\hline ISOM & 0 & 0 & 0 & 0 & 0 & 1.51 & 0 & 0 & 0 \\
\hline MTBE & 0 & 0 & 0 & 0 & 0.42 & 0 & 0 & 0 & 0 \\
\hline VHCR & 0 & 0.41 & 2.21 & 4.12 & 0.29 & 0 & 0 & 0.17 & 0.58 \\
\hline H-OIL & 0 & 1.62 & 6.56 & 0 & 0 & 0 & 0 & 0 & 0 \\
\hline VFCC & 0 & 4.90 & 6.57 & 6.16 & 6.57 & 1.26 & 6.41 & 4.06 & 1.59 \\
\hline RFCC & 0 & 1.89 & 2.54 & 2.38 & 2.54 & 0.48 & 2.47 & 1.57 & 0.61 \\
\hline COKR & 0 & 6.91 & 0 & 0 & 0 & 0 & 0 & 0 & 0 \\
\hline LUBE & 0 & 0 & 0.12 & 0.12 & 0 & 0.06 & 3.08 & 5.63 & 0.64 \\
\hline SULR & 0 & 0 & 0 & 0 & 0 & 0.57 & 0 & 0 & 0 \\
\hline & & & & & & & & 0 \\
\hline
\end{tabular}


LPG，ベンゼン，硫黄については生産量を与えず，モデル内で 自由に決定されるものとした。同様に, 電力C 重油 (CHO2E) は石油精製システムから電力供給システムへ外販されるので, 需要データは与えず，自由に決定される。

輸入ナフサの供給限界量はナフサ需要量の 2000 年度值を参 考にして，30.16[GL]とする。この輸入上限は，評価期間を通 じて変化しないものとした。価格は，2000 年度を 21.547 [GYen/GL]として，毎年0.4096[GYen/GL]づつ上昇するもの とした1)。

\subsection{7 ユーティリティ装置のモデル化}

Fig. 4のように石油精製モデルは石油精製装置とユーティリ ティ装置の 2 ブロックから構成されている。ユーティリティ 装置では，石油精製装置で必要となる蒸気や電力を製造する。 発電した電力は石油精製モデル内の電力需要を賄った上で, 余剰分が電源モデルに出力される。

ユーティリティを 6 種に区分した。それぞれ，FU，STM， PWR 等がある。

\section{2 .8 ボイラおよび電源装置}

(1) 製油所ボイラ：製油所ボイラ装置群では，燃料種（VR, HCVR，CK，FU）別にSBLRがあり，入力物質である VR やFU等の 4 物質を燃焼して, STMを得る。入力物質の燃 料発熱量にボイラ効率を乗じて出力を算出する。

（2）製油所電源：製油所電源群には，STGN，RIGC1，RIGC2, GTCCを含めた 4 装置がある。 4 発電装置について，発電 効率 $(\mathrm{HHV} \%)$, 所内率 $(\%)$, 建設単価 $(\mathrm{GYen} / \mathrm{GW})$, 運 転経費率 $(\mathrm{GYen} / \mathrm{GW})$ ，利用可能率 $(\%)$ を与えた。その 一部を Table 1 に示す。RIGC1 は 2000 年（ 0 期）以降で, RIGC2 は 2010 年（2 期）以降で，それぞれ選択可能とし た。この 4 装置と 5 種の燃料 $(\mathrm{STM} \sim \mathrm{FU})$ の組み合わせ から，選択可能な燃料の組み合わせの消費量を発電出力の 係数として与えた。なお, Table 1に示す装置群は連続運転 を行うため, Load classification は全てL4 とした。Table 1 の建設費は，電源モデルと石油精製モデルで大きく異な る。石油精製モデルでは，既存プラント内にユーティリ ティ供給設備として設置するため, 用地確保が不要なこと を想定した。

\section{3 エネルギー価格設定}

統合モデルが示す最適解は，エネルギー価格の影響を受け る。次節 3.3.1に示す一次エネルギー価格を基準として, 3.3 .2 に示すように，原油種別による価格の違いを考慮した。

\subsection{1一次エネルギー価格}

一次エネルギー価格として，WTI原油，一般炭，LNGを設 定し，統合モデルの基準価格とする ${ }^{20)} 21$ 。評価期間で，WTI 原油は30.4〜 $103.1[\mathrm{US} \$ / \mathrm{bbl}]$ へ，一般炭は4.14～ $9.32[\mathrm{kYen} /$ Ton]へ，LNGは27.92〜110.49[kYen/Ton]へ，それぞれ価格 上昇することを想定した。

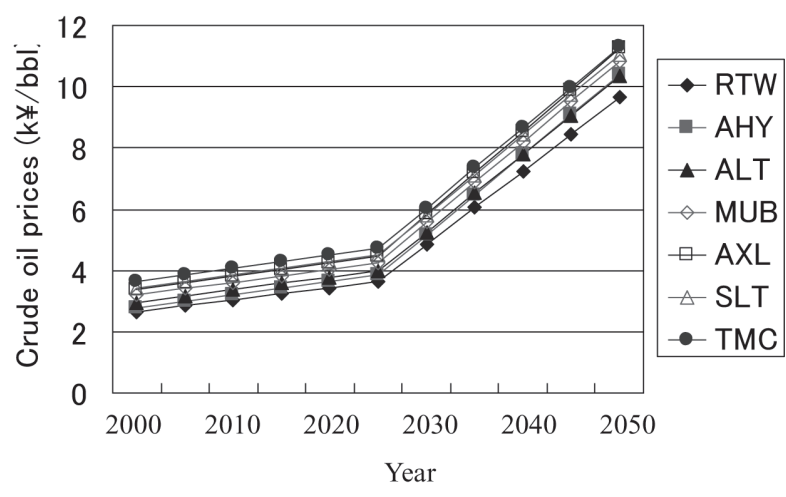

Fig. 5 Crude oil price assumption

\subsection{2 原油種別の価格設定}

原油価格は，油種によって異なり軽重格差が存在する。指 標原油であるWTI価格が上昇するとき，軽重格差も変化する。 本研究では，油種間格差変動に応じた石油残渣発生量と石油 精製システム構成の応答を分析することを目指すため，油種 別の原油価格を決定する必要がある。API比重をパラメータと して原油の軽重格差変動を統計的に求め， 7 種の原油につい て，評価期間である 11 期のそれぞれの価格を，Fig. 5 の通り 設定した。本設定はモデル構築時点の原油価格を参考にした。 直近の原油価格と比較すれば，RIGCの導入に有利な設定であ ることに注意すべきである。

\section{4. 最適化結果}

RIGCが，統合モデル内のエネルギーシステムにどのような 影響を与えるのかについて，最適化結果を用いて順に説明す る。

\section{1 原油投入量}

石油精製システムにおける原油投入量の期別の推移を, RIGC の有無に応じて Fig. 6 に示す。RIGC 有無による違いは ほとんど見られない。両ケース共通して，2000年から2030年 にかけて約 $36 \%$ の原油の減少が見られた。今後石油需要は減 少して傾向にあるが，同様に原油投入量も減少していくと予 想される。RIGC有りのケースで投入される原油種別の投入比 率（Fig. 7）から，主として超重質原油である RTW 原油が選 択されたことがわかる。RIGC無しのケースでも同様に，主と

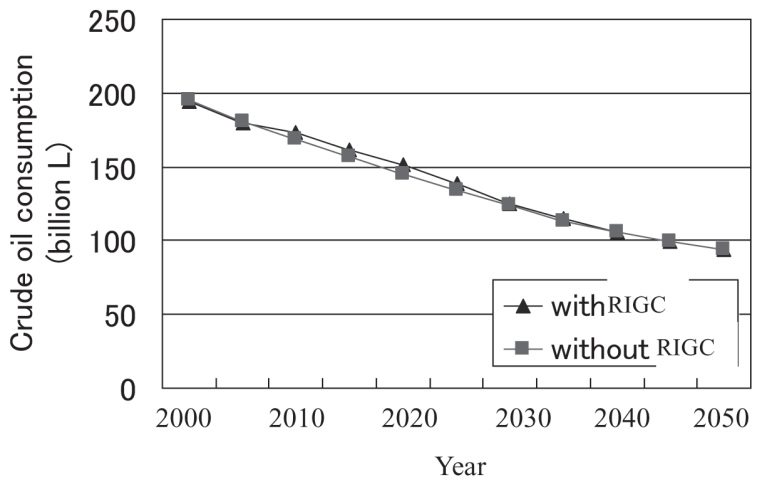

Fig. 6 Crude oil consumption 


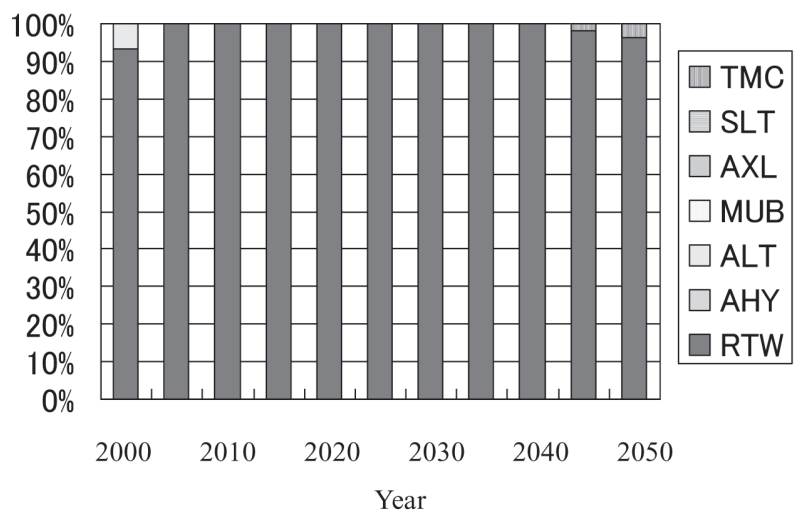

Fig. 7 Consumption rate by type of crude oil (RIGC introduction case)

してRTW 原油を選択した。精製コストの増加を考慮しても， 安価な重質油を選択し分解装置によって白油化する方が総合 的に優れていると判断されたと考えられる。

\section{2 電源構成}

電源システムの発電機別の発電電力量について, RIGCが有 る場合を Fig. 8 に, 無い場合を Fig. 9 に示す。両図には, 石 油精製システムの発電電力量も併記した。Fig. 8 と Fig. 9 は共 に, 前半期から中間期にかけて石炭火力COFが大きく増加す る。石炭火力がLOW電源として導入され発電量が増加したた めである。一方で LNG 火力 LNF, LNG 複合 LNC 等が, 前半 期のPEAK，HIGH電源として稼働した。中間期から後半期に かけては石炭火力が減少し, 代わりにCIGCが導入された。後

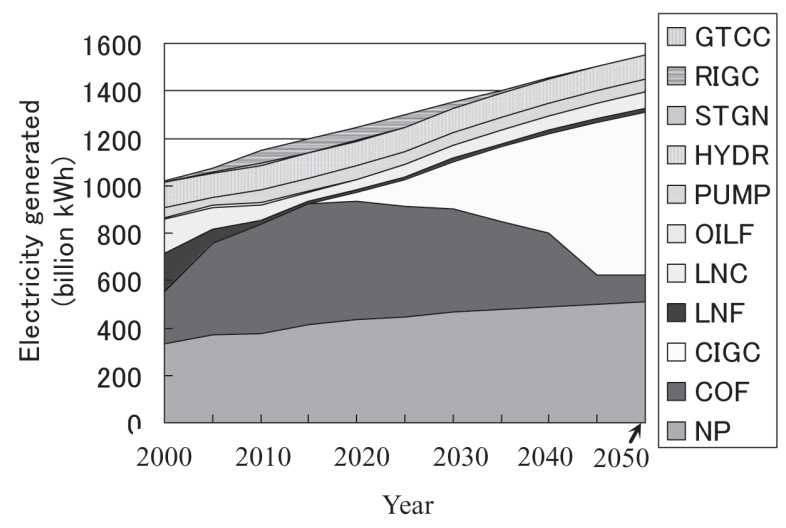

Fig. 8 Electricity generated (with RIGC)

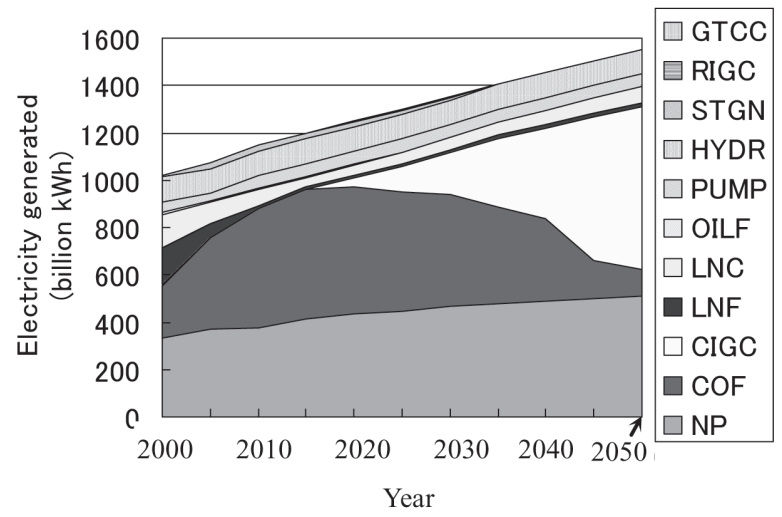

Fig. 9 Electricity generated (without RIGC)
半期になると化石燃料価格が上昇するため, 安価で高効率な CIGCにシフトしたと考えられる。RIGC有りのケース (Fig. 8) では，2005 年以降に約 7GW の RIGC が導入された。2015 2020年に稼働のピークが見られ，最大で日本の電力供給の 5 \%を石油精製システムで供給する可能性が有る。後半期に近 づくと原油価格が高騰するため RIGC の発電量は減少する。 RIGC が無い場合は 2005 年以降, 約 $3 \mathrm{GW}$ の残渣発電が導入 された。

\section{3 電力用 C 重油と余剩電力量}

4.1，4.2節では，石油精製モデルへの原油投入量（入力）と 電源モデルの発電電力量（出力）を示した。本節では, 石油 精製モデルから電源モデルへ引き渡される電力用 C 重油量と 余剰電力量を明らかにする。Fig. 10 に示す。電力用 C 重油 (CHO2E) は石油精製プラントで生産され, 電源モデルに石油 火力発電の燃料として引き渡される。余剩電力は, 石油プラ ントで発電された電力のうち, 石油精製プラントの電力需要 を差し引いた電力である。電源モデルに供給した C 重油の消 費量は RIGC の有無に関係なく徐々に減り続け, 2025 年にゼ ロとなる。石油火力発電は初期の PEAK 需要の電源として稼 働するが，2025年以降は石油火力発電を新設せず， LNG火力 発電と LNG 複合発電に代替され設備寿命の到来とともに フェーズアウトする。

余剩電力は RIGC の有無に関わらず，中間期に大きくなる が，後半期になると減少する。後半期に原油価格が高くなり， 石油精製プラントからの電力供給コストが上昇するためだと 考えられる。RIGC有りのケースでは, 中間期にRIGCが $7 \mathrm{GW}$ と大量に導入され，最大で 60 億 $\mathrm{kWh} /$ 年以上の電力を供給し た。RIGC無しのケースでは，石油精製プラントの発電機とし て石油残渣を燃料とする蒸気タービン発電機が約 $3 \mathrm{GW}$ 導入 されるが, RIGCと比べて発電効率が低く, 電力供給量は最大 で 25 億 $\mathrm{kWh} /$ 年未満となる。石油精製プラントが，電源シス テムの電力供給能力の一部を担う可能性があることが分かる が，RIGC を導入することによって更に増強される。

\section{4 石油精製における燃料別電力量}

4.1節の原油消費量の変動とFig. 10の傾向をより詳細に把握 するため, 石油精製プラントの燃料別の発電電力量をFig. 11

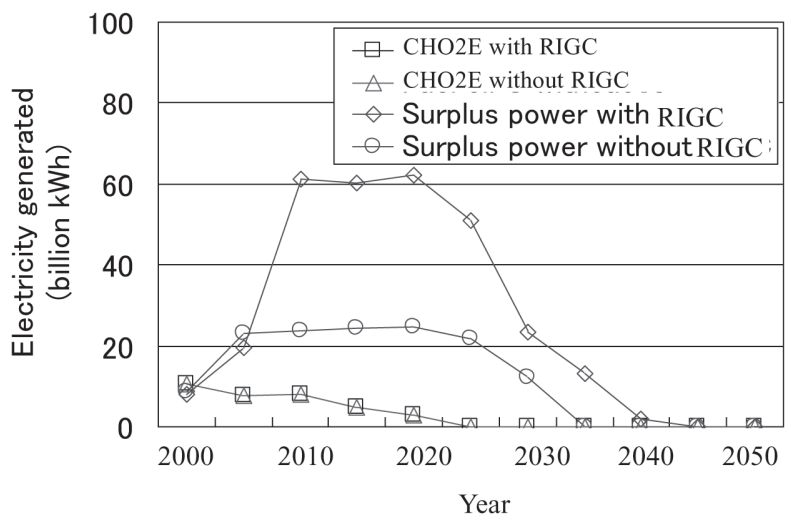

Fig. 10 Electricity generated by oil fuels 


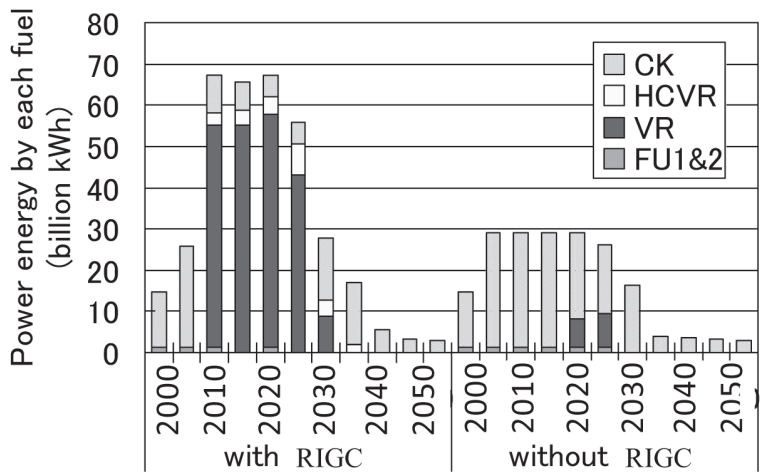

Fig. 11 Electricity generated in petroleum refinery model by fuel type

に示す。Fig. 11 に記載される燃料は, Fig. 4 に示したように, VRが減圧蒸留装置から得られる残渣を示している。VRを水 素分解して軽質留分を絞り取った残渣をHCVR，VRをCOKR に投入して出てくる残渣を CK と呼ぶ。COKRではVRから軽 油留分を取り出すことができる。FU1\&2は，C重油やLPG 等 の自家燃料である。

Fig. 11に示すように，RIGC有りのケースでは，2010２025 年に大量の VR を RIGC に投入して発電した。2000〜 2005 年 および2030年以降では，RIGCの燃料としてのVRの利用は削 減され，その代替としてVRを分解した残渣であるCKが小規 模に利用された。RIGC無しのケースでは，各期を通じて主に CK を用いて発電した。発電電力量は, RIGCの有無により, ピーク時で約 2 倍異なる。

このFig. 11から，石油精製システムにおける発電用燃料は CKが主体であるが，原油価格が比較的安価な前半期では，VR を燃料とする RIGCが優位なことがわかる。前述のようにVR は CK の原料でもあるため, RIGCによってVRの処理方法が 変化したと言える。

\section{5 水素製造装置稼働量}

前節で示したように，後半期では原油価格が上昇するため， 発電電力量は最小限に抑えられ，CK の消費量は削減される。 この削減されたCKは，水素製造の燃料として使用された。水 素製造装置の原料消費量をFig. 12に示す。水素は，主に石油 精製プラント内の脱硫装置と分解装置で利用される。Fig. 12 は，RIGCの有無に関わらず，後半期に向けて水素製造量が減

$\square$ LPG $\square$ VR $\square$ DLN $\square$ HCVR $\square$ CK

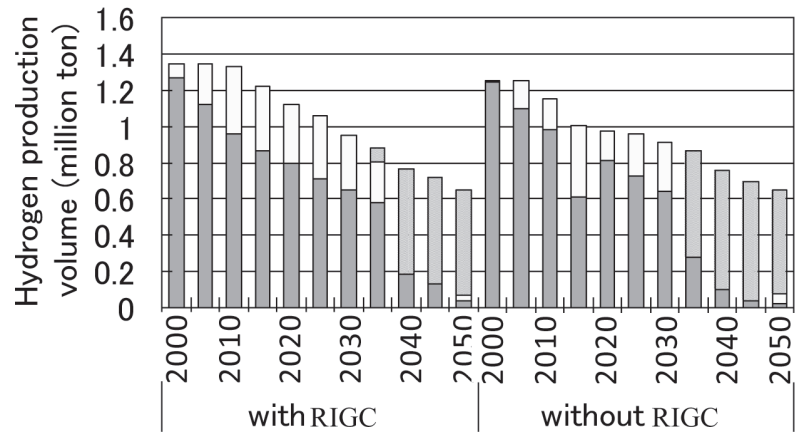

Fig. 12 Hydrogen production by fuel type
少していることを示している。その減少量は，2000年を基準 として，約 50\%減少しており，これは Fig. 6 の原油投入量の 減少と一致している。前半期にはLPG やナフサ (DLN) を利 用して水素が製造された。後半期になり原油価格上昇すると, 新設される水素製造装置には CK を原料とするガス化方式が 選択された。

石油精製システムにおける水素の製造原料は，LPG P DLN といった軽質な原料から，重質なCKに代替されることがわか る。この傾向は RIGC 有無の影響を受けない。

\section{6 蒸気供給ボイラ稼働量}

蒸気供給ボイラの燃料消費量を，燃料別に Fig. 13 に示す。 蒸気供給の燃料には各期を通じてCKだけが選択された。石油 精製システムの蒸気供給用の燃料として, RIGCの有無や原油 価格の変化に関わらず，CKが最も安価であることを示してい る。

RIGCの有無を比較すると，燃料選択は変化しないが，蒸気 供給量は変化した。RIGC無しのケースでは減少傾向であるの に対し，RIGC有りの場合は $2000 \sim 2025$ 年の蒸気製造量がほ ぼ一定である。RIGCがVRを発電燃料として大量に消費する ことに伴い，熱分解 (COKR) よりもVRからの軽質留分転換 効率が高い水素化分解 (H-OIL)の稼動が大幅に増える。COKR は蒸気を発生するがH-Oilは大量に蒸気を消費するため，蒸気 消費量が増加したと考えられる。

\section{7 残渣処理手法としての Residual IGCC の役割}

4.におけるこれまでの結果は，RIGCが燃料としてVR を選 択する場合に発電電力量が増加すること，また，蒸気や水素， 電力などのユーティリティは将来的に CK を中心として供給 されること，等を示した。そこで，CKの原料であるVRの処 理方法を Fig. 14 と Fig. 15 に示す。RIGC有りの場合 (Fig. 14)

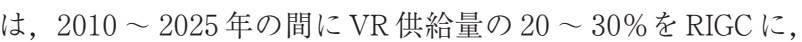
各期ほぼ一定の 40〜 50\%をCRACKに，残り 30〜 60\%をCOKR に投入した。RIGC 無しの場合（Fig. 15）は，VR 供給量の 17 〜 42\%を処理する CRACK と，60 80\%を処理する COKRで， 約 $90 \%$ を占める。両図を比較すると, RIGC の導入によって COKR が減ると共に, CRACK が増加する。COKR では CK だ けでなく蒸気も併産するが，FU2（主成分 LHC）を大量に消

$\square$ VR $\square$ HCVR $\square$ CK $\square$ FU1

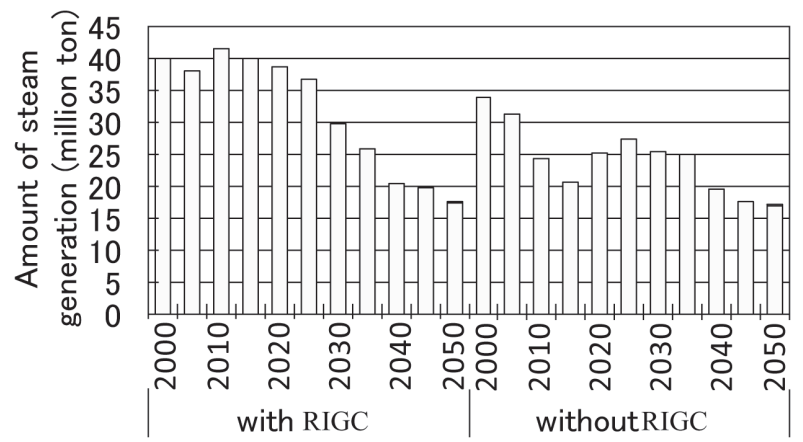

Fig. 13 Steam generation by fuel type 


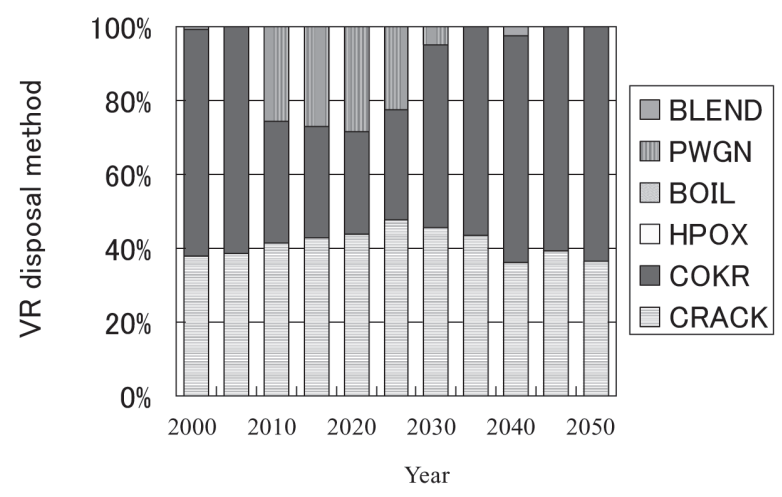

Fig. 14 VR disposal method (with RIGC)

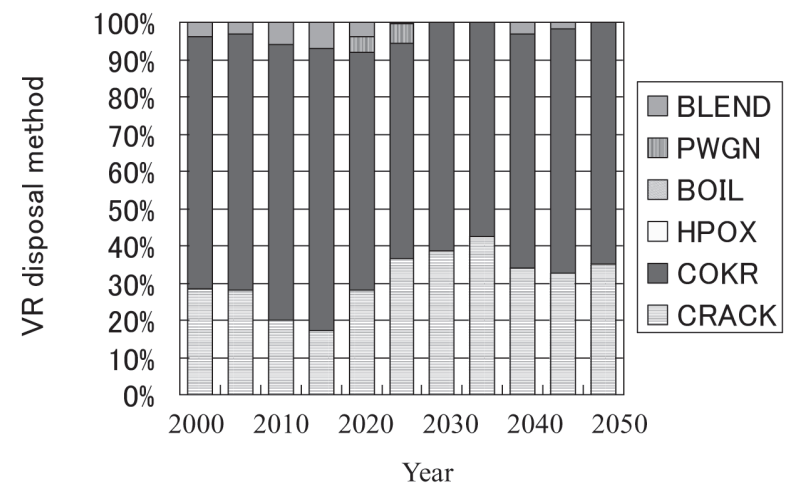

Fig. 15 VR disposal method (without RIGC)

費する。一方 CRACK が増加すると COKR より軽質分の供給 が増え，製品需要を満たすことができる。RIGCがVRを発電 用燃料として消費することに伴い，軽質製品の需要を満たす ためにCOKR と CRACK の稼動比率を調整したと言える。

将来, 原油価格が上昇し，また，軽質原油の入手が困難に なる方向であるが, VRから軽質分を取り出し, 残渣として出 てくるCKのみをユーティリテイ装置群の燃料とすることが 重要であり, 今後の石油精製の在り方だと考えられる。

\section{5. 結 言}

本研究は, 原油の重質化と石油需要の白油化への対応策と して，石油残渣IGCCを考慮した場合の導入インパクトを示す ことを主な目的とした。日本の石油精製システムと電力シス テムを統合した最適化モデルを構築し, 数值例により解析し た。最適化モデルの評価期間は 1 期 5 年 11 期間の計 55 年で, 線形計画法で記述される。本報告の結論として, 以下を挙げ る。

（1）熱分解，水素化分解により，超重質原油だけでも軽質化す る石油製品需要を賄うことは可能である。その際，分解残 渣は発電燃料として利用され，余剩電力は系統へ供給され る。

(2) 石油精製プラントへの石油残渣IGCCの導入ポテンシャル は約 $7 \mathrm{GW} り ，$ 電力システムの最大 $5 \%$ の電力を供給す ることが可能である。石油残渣IGCCが無い場合でも $3 \mathrm{GW}$ 程度の残渣発電が可能である。

(3) 石油精製プラント内の電力, 蒸気, 水素などのユーティリ
ティ供給は, 原油価格が上昇するにつれて, 最終的には石 油コークスCKで賄われる。現在では主にLPGや軽質ナフ サDLNが用いられる水素製造にもCK 用いるようにな る。

(4) 石油残渣IGCCが導入されると, 軽質油の需給をバランス させるため熱分解よりも白油化率の高い水素化分解が増え る。

本報告は，建設用地取得コストや想定原油価格の点で，石 油残渣IGCCが選択されやすい条件での結果と言える。また， 総コストの最小化を目的としており，二酸化炭素排出制約や， 原油価格の変化などの影響は明らかにされていない。これら の社会的な制約が変化した場合について, 今後, 更に明らか にしていく予定である。

なお，統合モデルを構築するにあたり，湊和春氏（元東京 農工大学大学院生物システム応用科学研究科), 遠藤陽一氏 (同大学機械システム工学科)のご協力をいただいた。この場 を借りて，関係各位に感謝の意を表する。

\section{文 献: References}

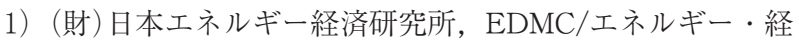
済統計要覧，p. 348-351 (2008) : The Institute of Energy Economics JAPAN, Handbook of energy \& economic statics in Japan, p. 348-351(2008)

2) 石油連盟, 今日の石油産業, p. 18(2009)：Petroleum Association of Japan, Petroleum Industry in Japan 2009, p. 18(2009)

3）石油連盟, 石油精製業における地球温暖化対策の取り組 み, p. $7(2008)$

4）経済産業省産業構造審議会統合エネルギー需給部会, 2030年のエネルギー需給展望 (2004)

5）産業構造審議会，技術戦略マップ(エネルギー分野), (2005)

6) (財)電力中央研究所 経済研究所, 電力中央研究所報告 研 究報告：579001電気事業に打ける長期限界費用の計測 (1979)

7）(財)地球環境産業技術研究機構，発電部門における発電技 術の特性・コストデータ想定，http://www.rite.or.jp/Japanese/labo/sysken/research/tech-assessment/importance/ importance-assumption.pdf

8）岩船由美子，民生部門における $\mathrm{CO}_{2}$ 排出削減施策の総合的 評価，東京大学博士論文，(2000)

9）(財)石油産業活性化センター，我が国の発電事業における 石油の位置付けの再評価(PEC-2003P-07)，（2003）

10) National Energy Technology Laboratory, Texaco Gasifier IGCC Base Cases (PED-IGCC-98-001) Latest Rev. Jane 2000, (2000)

11）資源エネルギー庁 電力・ガス事業部，電源開発の概要 (2004)

12) Haverly Systems Inc., Chevron Assay Library, http:// www.haverly.com/chevfram.htm(2005) 
13）石油学会, 石油精製プロセス，p. 82-223(2005)：The Japan Petroleum Institute, Petroleum Refinery Process, p. 82$223(2005)$

14）日本工業標準調査会，JIS K 2202 ：Japanese Industrial Standards Committee, JIS K 2202

15）(財)石油産業活性化センター，ガソリンオクタン価の変更 等による製油所設備への影響に関する調査報告, p. 50-58 (2004)

16）（財)石油産業活性化センター，平成16年度委託・外注報 告書 燃料品質改善による製油所での $\mathrm{CO}_{2}$ 排出量に関する調 査，p. 14-15(2005)

17）石油連盟，石油製品の品質と規格，p. 29(1997)

18）石油連盟，石油資料月報(2004)

19）経済産業省，新・国家エネルギー戦略，p. 24-25(2006)： Ministry of Economy, Trade and Industry, New National Energy Strategy, p. 24-25 (2006)

20）(財)電力中央研究所，2050年までの世界エネルギー需給 の長期展望(2003)：Central Research Institute of Electric Power Industry, World energy Supply and Demand Projections to 2050 (2003)

21）(独)経済産業研究所, 電源構成試算モデルと発電コスト比 較について (2003)

\section{Nomenclature}

A. 図表に関する略号

AHO : Product A Heavy Oil，製品 A 重油

AHY : Arab heavy，アラブ・ヘビー原油

ALKY : Alkylation，アルキレーション装置

ALT : Arab light, アラブ・ライト原油

AR : Atmospheric Residue，常圧残渣

ARHDS : Atomospheric Residue HDS，残渣脱硫装置

AXL : Arab extra light，アラブ・エクストラ・ライト原油

BLEND：Blender，燃料調合装置

CCRF : Continuous Catalyst regeneration Reformer，連続再生 式接触改質装置

CGSD : Cracked Gasoline HDS，分解ガソリン脱硫装置

CHO2E : C Heavy Oil for Power system, 電力用 C 重油 CHO2F：C Heavy Oil for General Purpose，一般用 C 重油 CIGC : Coal Integrated Gasification Combined Cycle，石炭ガス 化複合発電（石炭 IGCC)

CK : Pet Coke, 石油コークス

COF : Coal Fired Power Generation, 石炭火力発電

COKR : Coker，コークス製造装置(熱分解)

CRACK : Cracking Unit, 分解装置（水素化分解，接触分解）

CRD : Crude Oil, 原油

DBENZ：Benzen Separator，ベンゼン分離装置

DLN : Desulfurized Light Naphtha

FU1：Refinery Fuel Liquid，石油精製燃料（液体）

FU2：Refinery Fuel Gas，石油精製燃料（気体）

FUPR : Home Fuel Production，自家燃料製造装置
GHDS : Gas Oil HDS, 軽油脱硫装置

GO : Gas Oil, 軽油

GTCC : Gas Turbine Combined Cycle，ガスタービン複合発電 GUPGR：Gasoline Upgrader，高品質ガソリン基材製造装置

$\mathrm{H}_{2}$ : Hydrogen, 水素

H2S : HydrogenSulfide, 硫化水素

HCVR : Hydrocracked Vacuum Residue, 水素化分解残渣

HDS : Hydro Desulfurization, 脱硫装置

HN : Heavy Naphtha，重質ナフサ

HNHDS : Heavy Naphtha HDS，重質ナフサ脱硫装置

H-OIL : Vacuum Residue hydro-cracking

HPOX: Hydrogen Production (Partial Oxidation)，水素製造装

置（部分酸化法）

HPSR: Hydrogen Production (Steam Reforming)，水素製造装 置（水蒸気改質法）

HYDR : Hydroelectric Power Generation, 一般水力発電

ILUBE : Lube Oil, 潤滑油

ISOM : Isomerization，異性化装置

KERO : Kerosene, 灯油

KHDS : Kerosene HDS, 灯油脱硫装置

LHC : Light Hydrocarbon, 軽質炭化水素

LN：Light Naphtha，軽質ナフサ

LNC : Natural Gas Combined Cycles，LNG 複合発電

LNF : Natural Gas Fired Power Generation, LNG 火力発電

LNHDS：Light Naphtha HDS，軽質ナフサ脱硫装置

LPG : Liquefied Petroleum Gas，液化石油ガス

LUBE : Lube Oil Manufacturing，潤滑油製造装置

MTBE : MTBE production, MTBE 製造装置

MUB : Murban，マーバン原油

NP : Nuclear Power Generation，原子力発電

OILF : Oil Fired Power Generation, 石油火力発電

PASFA : Product Asphalt，製品アスファルト

PBENZ : Product Benzene, 製品ベンゼン

PCOK : Product Coke，製品コークス

PGAS : Product Gas，製品ガス

PGO : Product Gas Oil，製品軽油

PJO : Product Jet Oil，製品ジェット燃料

PKERO : Product Kerosene, 製品灯油

PLPG : Product LPG，製品 LPG

PLUBE : Product Lube Oil，製品潤滑油

PNAPH : Product Naphtha，製品ナフサ

PRG : Product Premium Gasoline，製品プレミアムガソリン

PSULF : Product Sulfur，製品硫黄

PU : Pumped Storage Scheme，揚水式発電

PWR : Power, 電力

REG：Product Regular Gasoline，製品レギュラーガソリン

RFCC : Residue catalytic cracking equipment, 残渣流動接触分 解装置

RFORM : Catalytic Reforming, 接触改質装置

RIGC: Residual Oil Integrated Gasification Combined Cycle，石 
油残渣ガス化複合発電 (石油残渣 IGCC)

RTW : Wafra ratawi，ラタウィ原油

SBLR : Steam Boiler, 蒸気ボイラ

SLT : Sumatra light，スマトラ・ライト原油

SRRF : Semi-regen Reformer, 固定床半再生式接触改質装置

STGN: Steam Turbine Generator, 蒸気タービン発電システム (BTG)

STM : Steam, 蒸気

SULF：Sulfur Recovery，硫黄回収装置

TMC : Thammama condensate, サママ・コンデンセート

TOPP : Atomospheric Distillation, 常圧蒸留装置

VACU : Vacuum Distillation, 減圧蒸留装置

VFCC : Fluid catalytic cracking, 減圧軽油流動接触分解装置

VGO : Vacuum Gas Oil, 減圧軽油

VHCR : Vacuum Gas Oil Hydrocracking

VHDS : VGO HDS, 減圧軽油脱硫装置

VR：Vacuum Residue, 減圧残渣

B. 数式に関する略号

AVAIL：電源の利用可能率

$\mathrm{C}$ : 各電源の設備容量

ECOST: 電源モデルの総コスト

EDEM : 時間帯別電力需要
FIX：電源モデルの固定費

FUEL：電源モデルの変動費

HIGH：ミドル負荷運転（高負荷側）

I : 電源設備の集合

$\mathrm{i}$ : 入力物質

$\mathrm{J}$ : ユーティリティ量

$\mathrm{k}$ : ユーティリティ種別

L1 ～L4：式(1)で定義される電力出力

LOW : ベース負荷運転

LS : 電源の所内負荷率

LVAL：電源の運用別負荷

$\mathrm{M}$ : 物質量

MID：ミドル負荷運転（低負荷側）

MPEAK：最大ピーク負荷運転

PEAK：ピーク負荷運転

$\mathrm{PU}$ : 揚水発電設備の揚水負荷

PUEFF : 揚水発電設備のエネルギー回収率

PWGN : 発電設備容量

$\mathrm{SPA}$ : 供給予備率

$X:$ 発電出力

XfrP：石油精製モデルの余剩電力量

$\alpha:$ 変換効率

$\beta$ : ユーティリティ消費率 